\title{
WATER QUALITY CHANGES IN IALOMIŢA RIVER UNDER THE INFLUENCE OF HUMAN SETTLEMENTS AND ACTIVITIES
}

\author{
Valentina-Mariana MANOIU ${ }^{1}$, A. BARSOIANU ${ }^{1}$, Mădălina NEDA ${ }^{2}$
}

\begin{abstract}
Water quality changes in Ialomiţa River under the influence of human settlements and activities. This article analyzes the evolution of the Ialomiţa River's water quality between 2005 and 2014 under the impact of several pressures, such as human settlements located along its course, human activities that generate wastewater which is subsequently dumped in the river and the practice of uncontrolled waste disposal on the banks or in the river's waters. Our approach relies on three types of information: 1) spatial data; 2) scientific literature review; 3) hydrological management data; and 4) water quality data. The paper presents various sources of domestic, agricultural and industrial pollution, which are all located along the river, and describes in detail their point or diffuse character. In relation to these pollution sources, we analyzed the repartition of the Ialomiţa River's waters into quality classes. The most significant human pressures come from diffuse sources, such as settlements lacking sewage collection and treatment systems or agricultural activities. Unregulated and inadequate landfills are an additional threat, not only for water quality but also for human health. Starting from 2010, no sector of Ialomița River was found to belong in the 4th or 5 th classes of water quality (highly degraded water). Nevertheless, there are several sectors that fall into the 3rd class (average water quality). There is an urgent need to create, and subsequently apply, viable and effective programs for eliminating the human pressures that were pointed out in the article.
\end{abstract}

Keywords: water quality, Ialomiţa River, pollution sources

\section{INTRODUCTION}

Due to Romania's unevenly distributed water resources across its territory and their seasonal variations (Frone and Frone, 2015), water quality is a major issue that should concern each and everyone. Our health depends directly on the source of our water, and human activities are behind the most severe pressures that affect surface waters, through the discharge of untreated or insufficiently treated waste water (Ion, 1999; Toma, 2002a,b; Toma, 2003; Pehoiu, 2008; Murarescu and Pehoiu, 2009; Pehoiu and Murarescu, 2010; Cosac et al., 2010; Dumitrache and Diacu, 2010; Matache et al., 2010; Popa et al., 2010; Dunea et al., 2013; Iordache et al., 2014; Manea et al., 2014).

${ }^{1}$ Faculty of Geography, University of Bucharest; Bd. Nicolae Balcescu nr.1, cod postal 010041, sector 1, Bucharest, Romania; valentina.mariana.manoiu@gmail.com (contact author), andrei.barsoianu@gmail.com

2 National Meteorological Administration, Sos. Bucuresti-Ploiesti nr.97, cod postal 013686, Sector 1, Bucharest, Romania; madalina.neda@meteoromania.ro 
In EU member states, water resource management is achieved in the context of the Water Framework Directive 2000/60/EC (WFD, 2000), whose goal is to reach a good ecological status for water bodies. This directive was transposed in Romanian legislation through Law no. 310/2004, adopted for amending and completing Water Law no. 107/1996, and also through other regulations, such as Order no. 161/2006 for approving the norms used in the classification of surface water bodies in view of determining their ecological status. The Water Framework Directive is implemented by means of River Basin Management Plans, which are elaborated and applied by River Basin Management Agencies, entities that belong to the National Administration of Romanian Waters, which is placed under the authority of the Ministry of the Environment, Water and Forestry, together with the Water Management Systems existing at county level.

In Romania, the Ialomița River basin is known to be affected by numerous pollution sources. It is located in the south eastern part of Romania (covering an area of $10350 \mathrm{~km}^{2}$ ), and Ialomița is a left-side tributary of the Danube. It has a length of $417 \mathrm{~km}$ and an average multi-annual flow of $41.7 \mathrm{~m}^{3} / \mathrm{s}$ at Slobozia (FRMP, 2015). Pollution mostly comes from human settlements located along its banks (such as Pucioasa, Fieni, Târgovişte, Urziceni, Slobozia), as well as from human activities that generate waste water, which is then discharged in the river, and from the uncontrolled storage of waste in the river or on its banks. Furthermore, Ialomița has three main tributaries, Cricovul Dulce, Prahova and Sărata, which all flow through industrial areas or regions with certain geographical particularities that can influence water quality.

Thus, the goal of this paper is to analyze the evolution of water quality of the Ialomița River in the period 2005-2014, in the context of the application in Romania of the Water Framework Directive. Our work updates and expands the body of information provided by previous papers on the same topic, which are mentioned above, and deals with the qualitative characteristics of Ialomița River's water, on the one hand, and the projects aimed at reducing pollution, on the other. The paper focuses on two main issues: 1) the main point and diffuse pollution sources on Ialomita River and 2) the qualitative changes in the river's water under the major human pressures.

For this study, we identified pollution sources using the Corine Land Cover (CLC, 2012) data base and information contained in the 2015 Buzau-Ialomita River Basin Management Plan (BIRBMP, 2015). The analysis of water quality and its classification in the different quality classes was performed using data from the Buzău-Ialomița River Basin Management Agency (BIRBMA).

\section{INVESTIGATION OF POLLUTION SOURCES ON IALOMIT,A RIVER}

Numerous human settlements are situated in the floodplain of Ialomiţa River, which damages the quality of the river's waters. Urban and rural settlements are intrinsically connected to the presence of both diffuse and point sources of 
pollution. Our analysis refers to the sources situated along the river and does not take into consideration other pollution sources located in the basin, which may influence the water quality of the Ialomiţa River. The main types of pollution generated by these sources are: pollution caused by organic substances, excessive levels of nutrients, and the discharge of harmful and dangerous substances.

\subsection{Point sources of pollution on Ialomița River}

The main point sources of pollution on Ialomiţa River are urban areas/human settlements, industrial sources and agricultural sites (BIRBMP, 2015).

Urban sources of pollution or human settlements that have access to waste water collection systems (which may or may not be equipped with water treatment facilities) that discharge directly in Ialomița (Fig.1) generate urban waste waters, and these contain mostly suspended matters, organic substances, nutrients but also heavy metals, detergents, hydrocarbons from oil etc., depending on the type of industrial activities and the level of treatment of industrial waste waters. In the case of Ialomița, the main urban pollution sources are the towns of Fieni, Pucioasa, Târgovişte, Urziceni, Slobozia and Țăndărei. It is important to note that none of the water treatment facilities existing in the Ialomița basin respects the existing legal requirements!

The most significant point sources of industrial pollution on Ialomița River (Fig.1) produce fertilizers (generating ammonia, urea and ammonium nitrate), sunflower oil, sugar and starch, whereas point agricultural sources of pollution are represented by poultry farms.

\subsection{Diffuse sources of pollution on Ialomița River}

The main diffuse sources of pollution on Ialomița River are human settlements situated along or near the river, together with various agricultural and industrial sources (BIRBMP, 2015).

Human settlements located near Ialomița (only 1\% of rural settlements benefit from a sewage system), which lack waste water collecting systems or adequate means of collecting and removing silt and mud from treatment stations, as well as villages where landfills do not meet existing environmental standards (Fig.1) generate diffuse pollution of the river's water. In the case of settlements that have sewage systems, none of them meets the requirements of Directive 91/271/EEC on treating urban waste waters, as amended by Directive 98/15/CE (BIRBMP, 2015). At the same time, inadequate management of household waste at town or village level represents another diffuse source of pollution. The development of urban areas must be accompanied by the construction of ecological landfills and the elimination of uncontrolled waste dumping, which is common along the banks of rivers and lakes.

Animal farms that do not possess adequate installations for collecting and storing manure, rural settlements identified as vulnerable or potentially vulnerable to nitrate pollution from agricultural sources, farms that do not respect existing rules and regulations on the use of pesticides and fertilizers, all of these elements 
can create significant diffuse emissions. The most important diffuse sources of pollution are located in the perimeter of settlements that are vulnerable or potentially vulnerable to nitrate pollution from agricultural sources, identified in accordance with the requirements of Directive no. 91/676/EEC on the protection of waters against nitrate pollution from agricultural sources (BIRBMP, 2015). In the upper course of Ialomița River, there are 6 such settlements, whereas in the lower course we find 100 settlements in this situation (BIRBMP, 2015).

Fig. 1. The map of water pollution sources in the Ialomiţa River drainage area

The diffuse sources of industrial pollution (Fig.1) are represented by storage sites for raw materials, finished goods or auxiliary products, or by places where waste products are kept in improper conditions, economic units that generate accidental pollution and abandoned industrial sites.

\section{THE EVOLUTION OF IALOMIȚA RIVER'S WATER QUALITY IN THE PERIOD 2005-2014}

The characterization of water quality, and subsequently of the ecological status of rivers, in accordance with the provisions of the Water Framework Directive, is based on a classification system comprising five quality classes: very good, good, moderate, poor and very poor (BIRBMP, 2015). A very good status is characterized by minor or non-existent anthropic alterations. Conversely, a very poor status is defined by severe alterations that lead to the absence of relevant 
biological communities.

The ecological status is characterized by the one-out, all-out principle and was evaluated using classification systems that are applicable to following elements (BIRBMP, 2015): biological elements (phytoplankton, macroscopic benthic invertebrates and fish fauna); general physicochemical elements (temperature conditions, oxygenation, acidification, and nutrients); specific pollutants.

In the analyzed interval (2005-2014), the quality of Ialomița River's water was monitored along its entire length of 417 kilometres. Taking into account all the previously mentioned pollution sources, Ialomița River's waters were classified as belonging in all the five quality classes, as presented in the table below (Table 1):

Table 1. Classification of Ialomița's waters into quality classes from a biological and physicochemical perspective, expressed in $\mathbf{k m}$ for sectors belonging to each class

\begin{tabular}{|c|c|c|c|c|c|c|c|c|c|c|c|}
\hline \multirow{2}{*}{ Year } & \multicolumn{9}{|c|}{ Quality class from a biological point of view } & \multicolumn{5}{c|}{$\begin{array}{c}\text { Quality class from a } \\
\text { physicochemical point of view }\end{array}$} & \multirow{2}{*}{$\begin{array}{c}\text { Total no. of km } \\
\text { monitored }\end{array}$} \\
\cline { 2 - 11 } & I & II & III & IV & V & I & II & III & IV & V & \\
\hline 2005 & 45 & 115 & 65 & 136 & 56 & 0 & 0 & 170 & 220 & 27 & 417 \\
\hline 2006 & 0 & 225 & 136 & 56 & 0 & 56 & 40 & 321 & 0 & 0 & 417 \\
\hline 2007 & 45 & 115 & 220 & 37 & 0 & 0 & 96 & 265 & 56 & 0 & 417 \\
\hline 2008 & 38 & 151 & 191 & 37 & 0 & 24 & 55 & 338 & 0 & 0 & 417 \\
\hline 2009 & 29 & 43 & 301 & 44 & 0 & 45 & 96 & 276 & 0 & 0 & 417 \\
\hline
\end{tabular}

For the 2005-2009 interval, we can see that 2005 was the last year when sectors of Ialomița River were rated in the $5^{\text {th }}$ class of water quality, both from a physicochemical point of view $(27 \mathrm{~km})$ and from a biological standpoint $(56 \mathrm{~km})$, and 2007 was the last year when Ialomița's waters on certain sectors $(56 \mathrm{~km})$ were rated in the $4^{\text {th }}$ quality class in terms of their physical and chemical state (Table 1, Fig.2 a, b).

In the 2005-2009 interval, the river's sectors that belonged in the $3^{\text {rd }}, 4^{\text {th }}$ and $5^{\text {th }}$ quality classes have one common characteristic: they are all located downstream (Fig.3) and are polluted by waste waters that have not been treated enough (or at all), generated by the main human settlements located along the banks of Ialomița and also by other sources, such as uncontrolled storage of waste, polluted waters coming from industrial sites and animal farms that do not store waste products (such as manure) in an adequate manner, together with water draining from farmland that has been treated with fertilizers and/or pest killers.

After 2010, the quality of Romania's water bodies, including Ialomița River, was expressed from an ecological perspective (integrated evaluation), and, on surface water bodies, the ecological status has been classified using the same five class system (Fig.2. c).

Beginning with 2010, no water body of Ialomița River was found to belong in the $4^{\text {th }}$ or $5^{\text {th }}$ quality class (poor or very poor ecological status), and the quality of Ialomița River's waters has thus improved (Fig.2. c), but there are nonetheless some water bodies that present only a moderate ecological status, which are located downstream (Fig.3) and present a risk in terms of their ability to reach a good ecological status, due to the impact of domestic, agricultural and industrial waste waters that reach Ialomița. 

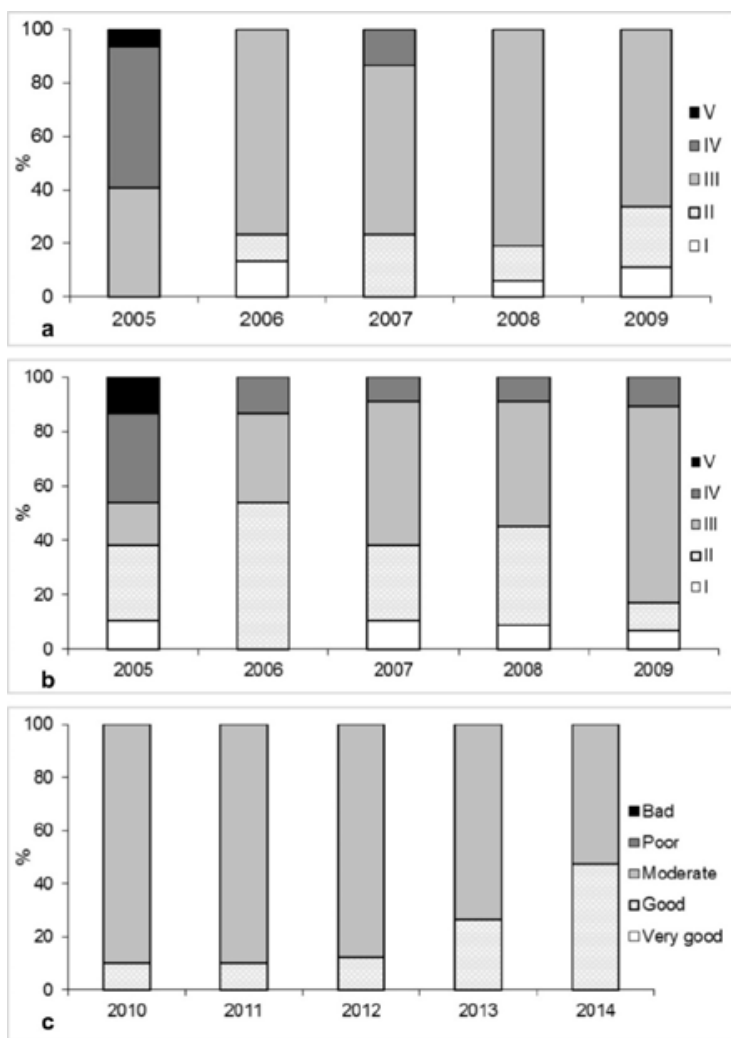

Fig. 2. Variations of the water quality of the Ialomița River between 2005 and 2014 according to data from BIRBMA, in \% of the river length (417 km): a) physicochemical quality; b) biological quality; c) ecological status

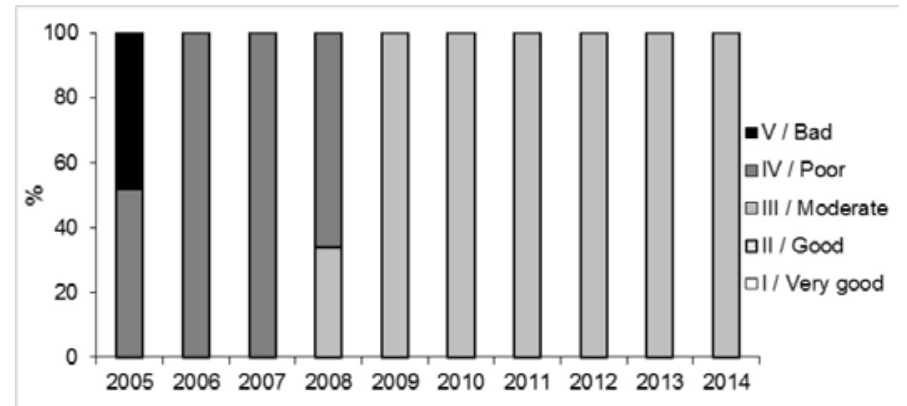

Fig. 3. Variations of the water quality (physicochemical and biological) and ecological status of the downstream reach of the Ialomița River between 2005 and 2014 according to data from BIRBMA, in \% of the reach length (56 km) 


\section{FUTURE PROJECTS AIMING AT SAFEGUARDING THE QUALITY OF IALOMIT,A RIVER'S WATERS}

In order to ensure an optimum ecological status of water bodies in the Ialomita River basin, it is necessary to implement a number of urgent projects: expanding sewage systems and improving the situation with regards to access to sewage services in human settlements near Ialomița; improving access to water treatment systems in human settlements located along Ialomiţa by building new water treatment stations and by repairing and upgrading existing ones (Târgovişte Sud, Pucioasa, Fieni, Bucşani, Comişani, Vulcana Pandele, Finta etc. in Dâmboviţa County, and Țăndărei, Coşereni, Fierbinţi Târg, Ograda, Căzănești etc. in Ialomița County); building environmentally friendly landfills and putting an end to the unrestricted practice of dumping waste and garbage, which is a common occurrence on the banks of Ialomita; building manure storage platforms for storing it during the prohibited application periods for fertilizers, fighting soil erosion, applying the principles of organic agriculture, counselling and trainings for farmers, applying and enforcing the Agricultural and Environmental Best Practices Code, in settlements like Moroeni (Dâmboviţa County), Bucu, Căzăneşti, Ciulniţa, Cosâmbeşti, Coşereni, Fierbinţi, Ograda, Perieţi, Țăndărei, Urziceni (Ialomiţa County); creating and maintaining buffer zones along the banks of Ialomița River.

\section{CONCLUSIONS}

It is clear to everybody that the most significant human pressures affecting Ialomița River come from diffuse sources of pollution located along the river, represented by human settlements lacking water treatment facilities and also from agricultural activities. Unregulated and inadequate landfills are an additional threat, not just for water quality but also for human health. As of 2010, Ialomița River no longer has sectors that fall in the $4^{\text {th }}$ or $5^{\text {th }}$ classes of water quality (highly degraded water). Despite this improvement, several sectors still belong to the $3^{\text {rd }}$ class (average water quality). Due to this situation, there is a pressing need to create, and subsequently apply, viable and effective programs for reducing, or even eliminating, the human pressures described above.

\section{REFERENCES}

1. Cosac A.C., Frasin L.B., Teodorescu S. (2010), The Impact of Human Activities on Ialomita River Quality, Advances in Waste Management $-4^{\text {th }}$ WSEAS International Conference on Waste Management, Water Pollution, Air Pollution, Indoor Climate (WWAI'10), WSEAS Press,144-147.

2. Dumitrache F., Diacu E. (2010), Study on the Seasonal Variation of Nitrogen Nutrients Content from Ialomita River Hydrographic Basin, Rev. Chim (Bucharest), 61(3), 328-332.

3. Dunea D., Iordache S., Pohoata A., Cosmin M. (2013), Prediction of Nutrient Loads from Wastewater Effluents on Ialomita River Water Quality Using SWAT 
Model Support, Annals. Food Science and Technology, 14 (2), 356-365.

4. Frone D.F., Frone S. (2015), The importance of water security for sustainable development in the Romanian Agri-Food Sector, Agriculture and Agricultural Science Procedia, 6, 674-681.

5. Ion C. (2002), Hydrochemical features and the quality of surface waters on the Ialomita river, Annals of Valahia University of Targoviste, Geographical Series 2(2), 271-272.

6. Iordache S., Dunea D., Ianache C. (2014), Optimizing Nutrients Removal from Municipal Wastewater Treatment Plants Using Computer Simulation, Rev.Chim (Bucharest), 65(2), 242-248.

7. Manea L., Manea I., Alexandrescu D. (2014), The Ecotoxicity Influence of Nitrite and Nitrate about Environment, Annals. Food Science and Technology, 15 (1), 178-182.

8. Matache M.L., David I.G., Matache M., Ropota M. (2009), Seasonal variation in trace metals concentrations in the Ialomita River, Romania, Environmental Monitoring and Assessment, 153, 273-279.

9. Murarescu O, Pehoiu G. (2009), Water Resources and Their Quality in Upper Ialomita River Basin, Present Environment and Sustainable Development, 3, 8396.

10. Pehoiu G. (2008), The Impact of Human Activities on Environmental Quality in Dambovita County, Present Environment and Sustainable Development, 2, 272285.

11. Pehoiu G., Murarescu O. (2010), Environment and water resources in Targoviste Plain (Romania), Water and Geoscience - Proceedings of the $5^{\text {th }}$ IASME/WSEAS International Conference on Water Resources, Hydraulics and Hydrology (WHH'10), University of Cambridge, WSEAS Press, UK, 90-95.

12. Popa D., Popa R., Vidu L., Suler A., Nicolae C., Marin M., Pogurschi E., Isfan N. (2010), Implication of the Manure Management at the Environment, Scientific Papers: Animal Science and Biotechnologies, 43 (2), 116-118.

13. Toma, L. (2002), Analysis of Environmental Impact of Farming Systems in Cazanesti, Romania. Agri-Environmental Indicators, Analysis of Environmental Impact of Farming Systems in Five Central and Eastern European Countries, University of Helsinki, Helsinki-Helsingfors, pp 77-98.

14. Toma, L. (2002), Farming Systems and Rural Community Welfare from an Environmental Perspective. A Case Study on Agricultural Nonpoint Source Pollution in Romania, Restructuring and Transition of Agrifood Sector and Rural Areas in Romania, Expert Publishing House, Bucharest, 412-421.

15. Toma L. (2003), Policy Recommendations for Pursuing a Sustainable Agriculture in a Small Rural Community in Romania, Sustainable Agriculture in Central and Eastern European Countries, Discussion Paper No. 13, 3-22.

16. *** (2000), Water Framework Directive (WFD) 2000/60/EC, http://www.rowater.ro/default.aspx, last accessed on December $7^{\text {th }}, 2016$.

17. *** CLC 2012, http://land.copernicus.eu/pan-european/corine-land-cover/clc2012, last accesed on January 7, 2017.

18. *** (2015), Buzău-Ialomiţa River Basin Management Plan (BIRBMP), http://www.rowater.ro/dabuzau/default.aspx, last accessed on January $7^{\text {th }}, 2017$

19. *** (2015), Flood Risk Management Plan (FRMP), Buzău-Ialomița River Basin Management Agency, http://www.rowater.ro/dabuzau/default.aspx, last accessed on January $7^{\text {th }}, 2017$. 